\title{
REVISITING FREEDOM OF CONTRACT IN THE CONTRACT OF CARRIAGE OF GOODS BY SEA UNDER THE ROTTERDAM RULES: SERVICE CONTRACTS IN DISGUISE?
}

\author{
Awwal Ilyas Magashi* \\ Abdulrashid Lawan Haruna**
}

\begin{abstract}
The historiography of international legal regimes regulating freedom of parties to the contract of carriage of goods by sea is replete with uncertainties and enmeshed in disarray thereby deflecting the much desired effort to have a uniform and acceptable convention. This article examines the issue starting from the era of unfettered "one sided" freedom of "leave it or take it syndrome" down to the regulated hegemony under the Hague/Hague-Visby, as well as Hamburg Rules. This raises the question: to what extent should the freedom of parties be regulated under the proposed Rotterdam Rules? In an attempt to answer this question, the article apprises the antecedents of parties' freedom under the existing anachronistic regimes in juxtaposition with the practice under the Rotterdam Rules with a view to promoting development of global commerce. The article further observes that the mechanism provided under the canopy of "volume contract" suggests a better package but with its attendant consequences. The article suggests the need for a holistic approach towards ratification of the Rotterdam Rules albeit, subject to some certain amendments with a view of eschewing the egocentric syndrome that pervaded the success of the Hamburg Rules by the major maritime players.
\end{abstract}

Keywords: Volume contract, liner conference, party autonomy, mandatory rules

Ph.D. Candidate, IIUM, and Lecturer, Bayero University, Kano, Nigeria.

Ph.D. Candidate, IIUM, and Lecturer, University of Maiduguri, Nigeria. 


\title{
MENGKAJI SEMULA KEBEBASAN BERKONTRAK DALAM KONTRAK PENGANGKUTAN BARANGAN MELALUI LAUT DI BAWAH KAEDAH-KAEDAH ROTTERDAM: KONTRAK PERKHIDMATAN YANG TERSELINDUNG?
}

\begin{abstract}
ABSTRAK
Kajian penulisan bersejarah tentang rejim antarabangsa pengangkutan yang mengawalselia kebebasan pihak-pihak dalam kontrak pengangkutan barangan melalui laut penuh dengan ketidaktentuan dan kecelaruan, seterusnya memesongkan usaha yang sangat dikehendaki untuk mewujudkan satu konvensyen yang seragam dan diterima. Kajian isu ini dalam makalah dimulakan dari era kebebasan sebelah pihak yang tidak terhalang dalam sindrom 'ambil atau lepaskan ia' sehingga hegemoni yang dikawalselia oleh Kaedah-kaedah Hague/Hague-Visby, serta Kaedah-kaedah Hamburg. Ini menimbulkan persoalan: sejauh manakah kebebasan pihak-pihak dikawalselia di bawah Kaedah-kaedah Rotterdam yang dicadangkan? Dalam percubaan menjawab soalan ini, makalah mengkaji amalan lalu kebebasan pihak-pihak di bawah rejim sedia ada beserta amalan di bawah Kaedah-kaedah Rotterdam dengan tujuan mempromosi pemajuan perdagangan global. Makalah seterusnya memerhatikan bahawa mekanisme yang diperuntukan di bawah kanopi "kontrak jumlah" mencadangkan pakej yang lebih bagus tetapi ini hadir bersama dengan kesan-kesannya. Makalah mencadangkan pendekatan yang holistik terhadap pengesahan Kaedah-kaedah Rotterdam tetapi tertakluk kepada beberapa pindaan yang menjurus kepada menjauhi sindrom egosentrik yang telah meresapi kejayaan Kaedah-kaedah Hamburg oleh pemain-pemain maritim yang besar.
\end{abstract}

Kata Kunci: kontrak jumlah, perjanjian liner, autonomi pihak, kaedah-kaedah mandatori 


\section{INTRODUCTION}

Generally, parties are allowed, and should be encouraged, to freely tailor their bargaining process. In support of this, principles of private international law acknowledge the force of the intention of parties as a motive for the law for legal certainty and respect for expressions of freedom of contract, which deserve backing. ${ }^{1}$ Prima-facie, international carriage of goods by sea would be severely undermined if there did not exist a legal framework, which caters for the protection and observance of a well-balanced parties' freedom for the purpose of promoting international trade. ${ }^{2}$ This becomes necessary when viewed from the background that a contract of carriage is an international undertaking involving different foreign elements.

Thus, it is not within the precinct of the court to intrude or rewrite or override contractual agreements mutually agreed to. ${ }^{3}$ In the same vein, a beehive of trade and expansion of commercial activities prompted courts to recognise party autonomy and strengthen the contractual relations from the perspective of international trade agreements. Pursuant to this, courts came to insist that a reciprocal attitude of recognition of judicial authority is a vital ingredient in fostering such relations. Chief Justice Burger was most candid on this issue. After recognising the autonomy of parties in the contract of carriage to freely select a forum to either litigate or arbitrate their dispute respectively, he states thus:

Broadly speaking, Private International Law or Conflict of Laws involves traditionally, three basic concepts i.e. International or territorial Jurisdiction of courts in civil and commercial litigation; Choice of law; and recognition and enforcement of foreign judgments. See Dicey Morris and Collins, On the Conflict of Laws, (London: Sweet \& Maxwell, 2006), 14.

2 Dammann Jens, "Freedom of Choice in European Corporate Law," Yale Journal of International Law 29, (2004): 477.

3 In some exceptional circumstances such as public policy, interference is justified. See Clarkson, Christopher MV, and Jonathan Hill, The Conflict of Laws (USA: Oxford University Press, 2011), 13. See also Silberman Linda, "Transnational Litigation: Is There a Field? A Tribute to Hal Maier," Vanderbilt Journal of Transnational Law 39, (2006): 1427. (Arguing that the growth of international litigation has been so great that it is now recognised as field onto its own); Reimann Mathias, "From the Law of Nations to Transnational Law: Why we Need a New Basic Course for the International Curriculum," Pennyslvania State International Law Review 22, (2003): 397. 
The expansion of American business and industry will hardly be encouraged if, notwithstanding solemn contracts, we insist on a parochial concept that all disputes must be resolved under our laws and in our courts... we cannot have trade and commerce in world markets and international waters exclusively on our terms, governed by our laws and resolved in our courts. ${ }^{4}$

It is against this background that this article analyses the concept of freedom of contract from the viewpoint of contract of carriage of goods by sea, with more emphasis on the Rotterdam rules. Before delving into the details of this, the article highlights the extent of such freedom from the following perspectives: pre-Hague regime; Harter Act regime; Hague Rules regime; Hague-Visby Rules regime; Hybrid Regime; Hamburg Rules Regime; and Rotterdam Rules regime. In addition to that the article examines the concept of Service Contract and its consequential reincarnation into Volume Contract under the Rotterdam Rules. Likewise, the extent of freedom accorded by Volume Contract under the Rotterdam Rules in contradistinction with what is obtainable under the existing regimes would also be analysed. Similarly, the implication of the Rotterdam Rules on the uniformity in the contract of carriage of goods by sea legal regimes would also be discussed. Finally, the article provides a summary account and certain conclusion.

\section{PRE-HAGUE REGIME}

By the early $19^{\text {th }}$ century, bills of lading were at first governed under the common law. Shipowners had almost unfettered freedom and discretion to dictate, unilaterally and unfairly, the terms of the

The Bremen v Zapata [1927] 407, US 1, 9. See also Wilson John, "Coming to America to File Suit: Foreign Plaintiffs and the Forum Non Conveniens Barrier in Transnational Litigation," Ohio State Law Journal 65, (2004):113. (Observing the fact that American courts still distrust many procedures employed by foreign courts, a notion that caused courts to be reluctant to dismiss a case in favour of a foreign court, particularly if the plaintiff was domiciled in the United States. In the same vein, Lord Diplock observes that the "judicial chauvinism" which dominated judicial sentiments previously, has now been replaced by "judicial comity." See The Abidin Daver [1984] A.C. 398, 411 (H.L.). In essence, courts took judicial notice of the fact that parties enjoy anatomy and freedom to couch their contractual terms devoid of undue interference. Courts are not there to police their contractual agreements. 
contract of carriage. They insert every exemption clauses imaginable; choose exclusively the law and the forum and standard form of clauses that exempt liability from their obligations in the contract of carriage. ${ }^{5}$ The situation has reached the extent where a carrier "accepted goods to be carried when he liked, as he liked, and wherever he liked."

To compound the miseries of cargo owners, the English courts were keen to uphold the laissez-faire philosophies of contract that permitted shipowners to exclude several of the basic responsibilities that would have been implied at common law. ${ }^{7}$ This development emphasised and deepened the lack of uniformity in the contract of carriage, and perhaps more fundamentally emphasised the chasms between the shipowners and cargo interests and thus the need to provide a fair balance. ${ }^{8}$ At that time, shipowners were considered as common carriers in the sense that they were strictly liable for the damage to the cargo in the course of carriage. ${ }^{9}$

Reiterating the strictness of the shipowner's liability under common law, Sir John Holt in his celebrated judgment in Coggs $v$ Bernard observes thus:

5 Faria Estrella and Jose Angelo, "Uniform Law for International Transport at UNCITRAL: New Times, News Players, and New Rules," Texas International Law Journal 44, (2008): 277.

6 Sturley, Michael F, "History of COGSA and the Hague Rules," Journal of Maritime Law \& Commerce 22, (1991): 1.

7 Gaskell Nicholas, Regina Asariotis, and Yvonne Baatz, Bills of Lading: Law and Contracts, (London: Informa Law, 2000), 11-101.

8 Hassan Bello, "Hamburg Rules: Challenges and Perspectives" (paper presented at $10^{\text {th }}$ Maritime Law Conference Seminar for Judges Organized by Nigeria Shippers Council, Abuja-Nigeria, February, 2009).

9 Sturley Michael, The Legislative History of the Carriage of Goods by Sea Act and the Travaux Préparatoires of the Hague Rules, (United States: Fred B Rothman \& Co, 1990), 22. Notes that: shipowners continued to enjoy this protection during the early $19^{\text {th }}$ century under a strict liability system. "In both common and civil law countries the carrier was held strictly liable for cargo damage or loss that occurred in the course of the conveyance unless it could prove (1) that its negligence had not contributed to the loss and (2) that one of the four excepted causes (act of God, act of public enemies, shipper's fault, or inherent vice of the goods) was responsible for the loss." 
... [t]he law charges this person (the carrier) thus entrusted to carry goods against all events, but acts of God and the enemies of the King. For though the force be ever so great, as if an irresistible multitude of persons should rob him, nevertheless he is chargeable. And there is a public establishment contrived by the policy of law, for the safety of all persons, the necessity of whose affairs oblige them to trust these sorts of persons that they may be safe in their ways of dealing; for else these carriers might have an opportunity of undoing all persons that had any development with them, by combining with thieves etc. and yet doing it in such a clandestine manner would not be possible to be discovered. ${ }^{10}$

In order to escape from the strict liability imposed by the common law, shipowners/carriers resorted to incorporating all sorts of exculpatory clauses in the bills of lading ${ }^{11}$ to such an extent that even negligence on the part of shipowners/carriers in the course of carriage could be completely exempted. ${ }^{12}$

The almighty shipowners dictated the terms in the bills of lading down the throat of the shippers who had no option but to swallow those incongruous terms. Thus, the so-called "freedom of contract" enabled a shipowner to carry goods "when he liked, as he liked, and wherever he liked."

10 [1874], L. R. 9 Q. B. 122

11 Peters Martin, "Jurisdiction and Multimodal Transportation: Bringing Uniformity of Carriage of Goods by Sea to the Shores of the United States," Michigan State Journal of International Law 17, (2008): 761. He notes that "the bills of lading became so lengthy, and the parties' respective rights and liabilities so difficult to ascertain, that even bankers were in doubt as to their security when discounting drafts drawn against bills of lading, cargo underwriters did not know the risks which they covered when insuring goods,... and carriers and shippers were in constant litigation."

12 Wallace Mary, "Instruments of International Commercial Harmonisation in England and Wales," (Ph.D. thesis, University of East Anglia, 2013), 66-72. The author observes that "[A]t that time a regime of complete freedom of contract prevailed in this area of English law, and when the movement from wooden ships and the introduction of screw vessels, cable communication, radio and refrigeration caused radical changes in the shipping industry, carriers used this freedom to draft clauses which excluded their liability in many and sometimes virtually all circumstances, including cases where they were negligent."

13 Frederick David, "Political participation and Legal Reform in the International Maritime Rulemaking Process: from the Hague Rules to the Hamburg Rules," Journal of Maritime Law \& Commerce 22, (1991): 81. 
British Parliament where they played a crucial role in safeguarding the interest of shipowners. ${ }^{14}$

This over-bearing pressure prompted the United States of America to come up with a legislative backing to support its numerous shippers and cargo owners who were at the receiving end of the domineering attitude of the British shipowners. ${ }^{15}$

\section{THE HARTER ACT}

To address the unfettered freedom enjoyed by the shipowners, the Harter Act was enacted. ${ }^{16}$ The enactment of the Harter Act heightened

14 Fredrick David, Ibid.,84. He comments that the situation continued until early 1920s, neither judges nor lawmakers in England paid the necessary attention to the plight of the shippers/cargo owners. Even when cargo owners did win in the English courts, carriers moved quickly to insert exceptions into the bills of lading. At an early session at The Hague, Lloyds Bank representative W. W. Paine expressed the widespread frustration with this practice: "[P]ractically whenever a case has been decided against the shipowners on foot of a bill of lading for carriage of goods by sea-they always have the best lawyers in attendance at the Courts watching those cases-they have introduced an exception into the bill of lading to get rid of that case." International Law Association, Report of the Thirtieth Conference 52-53 (1922) (hereinafter Hague Conference Report), reprinted in 1 The Legislative History of the Carriage of Goods by Sea Act and The Travaux Preparatoires of the Hague Rules 158-59

15 Knauth Arnold Whitman, American Law of Ocean Bills of Lading, (New York: Oceana Publications, 1953), 39. estimates that 20 British liner companies carried nearly all of the American export trade. See also Frederick David, "Political participation and Legal Reform in the International Maritime Rulemaking Process: from the Hague Rules to the Hamburg Rules," Journal of Maritime Law \& Commerce 22, (1991): 84. The author notes further that: "American cargo interests became increasingly vulnerable to clever lawyering on behalf of British shipowners as ocean trade became more sophisticated through the elaboration of shipping documents, banker's drafts, bills of lading, insurance policies, and methods to subrogate tort and contract claims for damages and to avoid or defend such claims. Litigation exposed vast differences among the attitudes of American, English, and European courts concerning the nature of the carrier's obligations and the propriety of contracts exonerating carriers from their general maritime liabilities. The European and English courts routinely upheld contracts of exoneration, but American courts typically struck them down. In the United States, powerful cargo-shipping interests were less able to bring claims because English carriers included choice of law and forum clauses in their bills of lading that shifted the focus of the litigation from America to Britain."

16 Harter Act, 1893. Several other countries followed the lead of US by enacting law modeled on the Harter Act mutatis mutandis. For instance: New Zealand 
the need to checkmate the impunity of shipowners and promoted a compromise between the conflicting interests of carriers and shippers respectively. ${ }^{17}$ Though, a bold attempt in the right direction, the Harter Act eventually turned out to be a disappointment. ${ }^{18}$

The inadequacy of the Harter Act opened the Pandora box by various stakeholders in the shipping industry, especially the shippers/cargo owners for the agitation of a uniform international legal regime regulating contract of carriage. The shipowning countries did not want the principle of freedom of contract to be abridged, but they recognised that there was a need for reform and it came to be realised that a solution would have to be reached on an international basis between the two interest groups. ${ }^{19}$

\section{THE HAGUE RULES}

In a sequel to this development, the Maritime Law Committee of the International Law Association (ILA) in September 1921 at the Hague, constituted a committee represented by various shipping interests and

enacted Shipping and Seamen Act

Act, 1904 (Cth); and Canada - Water Carriage of Goods Act 1910 (Can). There were indications that many countries were threatening to evoke similar defences. The implication was that carriage of goods by sea and by extension, an international trade was under the threat of plethora of rules of anarchical proportions.

17 Treitel Guenter and Thomas Gilbert, Carver on Bills of Lading, (United Kingdom: Sweet \& Maxwell, 2011), 17. Observes that the Harter Act imposed certain of the old common law obligations on the carrier, and made it illegal to diminish these specific obligations under the bill of lading. In the interests of protecting the shipper, it was provided that it was not lawful for a sea carrier to exclude or limit his liability in respect of negligence as to the care of cargo, and that clauses purporting to to do so were void; and that it was not lawful for a sea carrier to exclude or limit his liability to exercise due diligence in respect of seaworthiness.

18 Mandelbaum Samuel Robert, "Creating Uniform Worldwide Liability Standards for Sea Carriage of Goods Under the Hague, COGSA, Visby and Hamburg Conventions," Transport Law Journal 23, (1995): 471. This is owing to the fact that the Act did not avail shippers with a real answer to the tricky and oppressive exculpatory clauses in the bills of lading, nor did it establish any affirmative rules of law. It failed to change the validity of the low valuation clauses, stringent notice of claims or short limitation periods.

19 Funke Agbir (Mrs.), "Cargo Claims: Third Party Rights and Duties" (paper presented at $2^{\text {nd }}$ Maritime Seminar for Judges organized by Nigeria Shippers Council, Abuja, Nigeria, May, 1999). 
saddled it with the task of producing the "Draft Rules." In 1924, the deliberations yielded the desired result of producing the first uniform international legal regime on the contract of carriage, which was code-named "The Hague Rules." 20 The breakthrough of coming up with the Hague Rules was a welcoming development most importantly on the part of shippers, which led to its adoption by both developed and developing countries. ${ }^{21}$ The United Kingdom was one of the biggest signatories to the Hague Rules and the same was domesticated by virtue of the Carriage of Goods by Sea Act (COGSA) $1924 .^{22}$ Subsequently, the Hague Rules were domesticated in the United State pursuant to the Carriage of Goods Act in 1936, thereby triggering the exodus of other powerful maritime European

20 International Convention for the Unification of Certain Rules of Law Relating to Bills of Lading, done at Brussels, on 25 August, 1924 and came into force as of $2^{\text {nd }}$ June, 1931.

21 Hamid Abdul Ghafur, "A New Carriage of Goods by Sea Act for Malaysia: A Holistic Approach on the Basis of International Practice," Journal of International Maritime Law 12, no. 3 (2006): 206. He observes that Malaysia domesticated the Hague Rules by the enactment of Carriage of Goods by Sea Act 1950, Act 527. "It was first enacted as the Carriage of Goods by Sea Ordinance (ordinance No. 13 of 1950), which entered into force on $23^{\text {rd }}$ May, 1950 and was revised on $14^{\text {th }}$ Nov. 1994; text available at http://www.lawnet.com.my." Accessed on 12 October, 2013. See also, Joseph Jeremy, "Carriage of Goods by Sea: Hague-Visby for Malaysia,?"[1998]." Maritime Law Journal 1, (1998): 1, observing that when the Rules were enacted in Malaysia by virtue of the Carriage of Goods by Sea Ordinance of 1950, Article 10 was omitted (though the rest of the Rules were scheduled to the Act) and the scope of application was restricted in the Ordinance itself under section 2. The Ordinance was revised in 1994 and section 2 of the Act now states: "Subject to this Act, the Rules set out in the First Schedule ... shall have the effect in relation to and in connection with the carriage of goods by sea in ships carrying goods from any port in Malaysia to any other port whether in or outside Malaysia."

22 Baughen Simon, Shipping Law, (London: Cavendish, 2012), 14. It was applicable to the outward shipment i.e. shipments from the UK. Bill of Lading must contain a statement that the contract of carriage incorporated the Rules under the technique referred to "as "clause paramount". Thus, section 3 of the 1924 (COGSA) Act provided: "Every bill of lading or similar document of title issued in Great Britain or Northern Ireland which contains or is evidence of any contract to which the Rules apply shall contain an express statement that it is to have effect subject to the provisions of the said Rules as applied in this Act." 
nations to follow suit. At the commencement of World War II, a great number of the world's shipping countries adopted the Hague Rules. ${ }^{23}$

It is important to note that the main thrust of the Hague Rules was to abridge the unfettered freedom enjoyed by the shipowners by providing a minimum threshold upon which parties must not derogate from. This major break was achieved by accommodating standard contractual clauses imbedded in the bill of lading. ${ }^{24}$ For instance, a minimum threshold of the carrier's contractual obligations ${ }^{25}$ as well as corresponding maximum contractual exceptions available to the carrier was provided. ${ }^{26}$ More importantly, a "policeman clause" was inserted to prevent contracting out by providing that any attempt to derogate or lessen these obligations will be "null and void and of no effect." ${ }^{27}$ The Rules apply to all bills of lading issued in any of the contracting States and define the scope of the application to cover the "period from time when the goods are loaded on to the time they are discharged" (tackle to tackle). ${ }^{28}$ Notwithstanding the classic rule of tackle to tackle, the Rules may apply to cover the whole contract of carriage if the parties so wish. ${ }^{29}$

23 The list of the Contracting States to the Hague Rules, are made available at http://comitemaritime.org/Uploads/Yearbooks/Yearbook\%2013.pdf Accessed on $11^{\text {th }}$ October, 2013.

24 Wilson John, Carriage of goods by Sea, (London: Pearson Education, 2007), 67.

25 Article III of the Hague Rules

26 Article IV of the Hague Rules

27 Article III r. 8 provides that "[A]ny clause, covenant, or agreement in a contract of carriage relieving the carrier or the ship from liability for loss or damage to, or in connection with, goods arising from negligence, fault or failure in the duties and obligations provided in this article or lessening such liability otherwise than as provided in these Rules, shall be null and void and of no effect." Although, Article V allows the carrier to agree to increase its liabilities or decrease its defences.

28 See Article 2 of the Hague Rules. "Tackle to Tackle presupposes the moment when ship's tackle is hooked on at the loading port until the moment when the ship's tackle is unhooked at discharge. If shore tackle is being used, that moment has traditionally been when the goods cross the ship's rail." Per Devlin J. In Pyrene Co. Scindia Steam Navigation Co. [1954] 2 Q.B. 402.

29 This is made possible pursuant to Article 7 of the Rules which provides that "Nothing herein contained shall prevent a carrier or a shipper from entering into any agreement, stipulation, condition, reservation or exemption as to the responsibility and liability of the carrier or the ship for the loss or damage to, or in connection with, the custody and care and handling of goods prior to the loading on, and subsequent to, the discharge from the ship on which the goods are carried by sea." 


\section{THE HAGUE-VISBY RULES}

After about five decades of coming into force of the Hague Rules, cracks began to appear in the armour of uniformity. ${ }^{30}$ Practical application revealed that the Hague Rules have failed to provide the balance between the developed maritime nations and developing or cargo interest nations. ${ }^{31}$

In 1963, Comité Maritime International Conference in Stockholm was convened, which culminated in some amendments to the Hague Rules. The draft protocol was formerly adopted at the $12^{\text {th }}$ Maritime Diplomatic Conference at "the historic city of Visby on the Swedish island of Gotland in 1968." 32 The Visby amendments do not significantly or radically depart from the Hague Rules and as such are neither a separate convention nor do they stand alone, but are rather, treated together and are appropriately called the Hague-Visby Rules. ${ }^{33}$

30 Some of the major shortcomings of the Hague Rules are: limited period upon which the carrier is liable i.e. (tackle to tackle); deck cargo is excluded; narrow scope of the rules leading to conflict of laws problems narrow scope of liability of the carrier; unrealistic of carrier's exemption for "act, neglect, or default of the master or servants"; low and almost depleted value of the maximum limit of carrier's liability (100 GBP per unit or package); and incompatible with the modern trade (containerization/electronic commerce)

31 Reimann Mathias, "From the Law of Nations to Transnational Law: Why we Need a New Basic Course for the International Curriculum," Pennyslvania State International Law Review 22, (2003): 397.

32 Ibid. It was observed by the author that "The Hague Rules 1924, as amended by the Visby Protocol of 1968, were further amended by the "Protocol Amending the International Convention for the Unification of Certain Rules of Law Relating to Bills of lading (August 25, 1924, as Amended by the Protocol of February 23, 1968), adopted at Brussels, December 21, 1979, which Protocol came into force on February 14, 1984. The 1979 SDR Protocol changed the basic unit of account of the Hague/Visby Rules 1968 from Poincaré gold francs to Special Drawing Rights ("S.D.R.'s") of the International Monetary Fund (I.M.F.). For this reason, the 1979 Protocol is sometimes called the "Visby S.D.R. Protocol."

33 Reynolds Francis, "Hague Rules, the Hague-Visby Rules, and the Hamburg Rules," Australian \& New Zealand Maritime Law Journal 7, (1990): 22. In response to the question of what then are the Hague-Visby Rules observes that: "[T]hey are simply Rules with a fairly small number of alterations, some of them quite important but not all very conspicuous. The main bulk of the HagueVisby Rules is exactly the same as the Hague Rules. They are Hague with certain alterations made in the interests of correcting particular difficulties perceived then as having emerged from the operation of the Hague Rules over 44 years." Similarly, Article 6 of the Protocol provides that: "As between the Parties to this Protocol the Convention and the Protocol shall be read and 
In essence, the Hague-Visby Rules are a mere face-lift to the Hague Rules, as the form and structure of the original rules remained unchanged. ${ }^{34}$ Subsequently, the Hague-Visby Rules enjoyed a great deal of patronage by most of the world's shipping nations. ${ }^{35}$

Notwithstanding the overwhelming acceptance in the midst of the commercial interests, the Hague-Visby Rules are far from being appealing to receive the "political muscle" sufficient to command its application on a global scale. ${ }^{36}$

\section{THE HAMBURG RULES}

Developing countries were unimpressed with the Hague-Visby Rules. In 1968, the United Nations Commission on International Trade Law (UNCITRAL) $^{37}$ commenced the re-examination of the rules

interpreted together as one single document. A Party to this Protocol shall have no duty to apply the provision of this Protocol to bills of lading issued in a State which is a Party to the Convention but which is not a Party to this Protocol." Gaskell, Nicholas, Regina Asariotis, and Yvonne Baatz, Bills of Lading: Law and Contracts, (London: Informa Law, 2000), 11-101.

35 It was adopted in the UK by virtue of Carriage of Goods by Sea Act (COGSA) of 1971 U.K. c. 19 and subsequently came into force on June 23, 1977 thereby repealing the Carriage of Goods by Sea Act 1924. The 1971 Act applies to all bills of lading issued in the United Kingdom or to any bill of lading issued in any Visby Rules Contracting State. Section 1(6)(b) makes a non-negotiable receipt (waybill) subject to the Rules by force of law if: it is marked nonnegotiable; it constitutes a contract of carriage of goods by sea; and it contains an express provision that the Rules are to govern as if the receipt were a bill of lading. See The European Enterprise [1989] 2 Lloyd's Rep. 185 at 189; The Verschroon [1982] 1 Lloyd's Rep. 301 at pp. 304-305. However, the US is not a party to the Hague-Visby Rules but decided to stay put with the Hague-Rules. Apart from UK, several other countries such as Belgium, East Germany, Denmark, France; Norway, Poland; Sweden; Switzerland; Ecuador; Lebanon; Singapore and Syria have ratified or acceded to the Hague-Visby Rules.

Sturley Michael, "The UNCITRAL Carriage of Goods Conventions: Changes to Existing Law," CMI Year Book, (2007-2008).

37 The United Nations Commission on International Trade Law (UNCITRAL) is the core legal body of the United Nations system in the field of international trade law. Its mandate is to remove legal obstacles to international trade by progressively modernizing and harmonizing trade law. It prepares legal texts in a number of key areas such as international commercial dispute settlement, electronic commerce, insolvency, international payments, sale of goods, transport law, procurement and infrastructure development. UNCITRAL also provides technical assistance to law reform activities, including assisting Member States to review and assess their law reform needs and to draft the 
regulating contract of carriage, culminating in the adoption of the UN Convention on the Carriage of Goods by Sea in Hamburg, in 1978 (Hamburg Rules), which will come into force on the first day of the month following the expiry of one year from the date of the twentieth ratification. ${ }^{38}$ The Hamburg Rules entered into force on $1^{\text {st }}$ November 1992 and have so far "been ratified by 34 states estimated to represent overall some 5 percent of world trade," a significant degree of support but which falls far short of that needed to produce uniformity. ${ }^{39}$

The Hamburg Rules certainly caused a stir in maritime law but was largely ignored by maritime nations. ${ }^{40}$ It took thirteen years (from 1978-1991) to obtain twenty ratifications of the Rules. Of the countries which have ratified the Rules, fifteen are African and about seven are landlocked and many have court systems with little experience of maritime law, whose judgments may not be substantially affected by the ratification of one set of rules or another. $^{41}$

The Hamburg Rules, in contrast to the Hague-Visby Rules, have been described as a cargo friendly convention, probably because its scope of application (port to port) not only reflects the modern approach to international trade, but stretches the period of responsibility and likewise, the carrier's liability. ${ }^{42}$ It has however, failed to establish an appropriate balance of freedom of contract. In

legislation required to implement UNCITRAL texts. The UNCITRAL Secretariat is located in Vienna, Austria. UNCITRAL maintains a website at www.uncitral.org.

Article 30 of the Hamburg Rules provides that this Convention enters into force on the first day of the month following the expiration of one year from the date of deposit of the twentieth instrument of ratification, acceptance, approval or accession. In October 1991, Zambia became the twentieth country to ratify the Hamburg Rules which came into force in 1992.

39 Anthony Diamond, "The Rotterdam Rules," Lloyds Maritime and Commercial Law Quarterly 6, (2009): 445.

40 Majority of the maritime key players including USA and UK are not signatories to the Hamburg Rules.

41 Sweeney Joseph, "The Uniform Regime Governing the Liability of Maritime Carriers," Diritto Marittimo 94, no. 4 (1992): 964.

42 Article 14 of the Hamburg Rules. It is worth noting that Hamburg Rules are more favourable to shippers and consignees than the carriers. For instance, it expanded the definition of "goods" to include animals and cargo carried on deck. It also drew distinction between a "contracting carrier" and "actual carrier", extended the the period of responsibility of carriers over goods entrusted to their care, penalty for delayed delivery of cargo which is limited to 2.5 times of freight paid e.t.c. 
essence, the Hamburg Rules was enmeshed with the raging attack and counter attack between the interests of shipowners and shippers, with the former strongly advocating for its rejection and the latter advocating for its acceptance.

These unending altercations compounded the misery of the Hamburg Rules by being a major flop on the part of UNCITRAL because major commercial and maritime powers have not adopted it and it has not been able to replace the Hague-Visby Rules as the dominant convention for the international carriage of goods by sea. ${ }^{43}$ The competition between the two regimes (Hague-Visby versus Hamburg) is quite a natural one and it reflects the competition between carrier interests and cargo interests. The primary objective of the unification of the law governing contract of carriage has already been frustrated by the conflict of interests within the shipping industry itself.

\section{THE ROTTERDAM RULES}

Driven by the need to stall further fragmentation, stabilise and establish an appropriate balance of contractual freedom between parties, promote legal certainty and actualise harmonization of the law governing contract of carriage, a new legal regime was proposed and adopted by Resolution 122 of the $63^{\text {rd }}$ session of the United Nations General Assembly on $11^{\text {th }}$ December 2008, at Rotterdam, The Netherlands. ${ }^{44}$ The Convention is not yet in force. ${ }^{45}$ Article 94(1) of the Convention provides that:

43 Hamid, Abdul Ghafur, "A New Carriage of Goods by Sea Act for Malaysia: A Holistic Approach on the Basis of International Practice," Journal of International Maritime Law 12, no. 3 (2006): 206. At present, 52 States consisting virtually of all the world's key maritime nations, adopt the HagueVisby Rules, while some trading countries have adopted laws that combine elements of the Hague-Visby and Hamburg: known as hybrid regime. For the list of contracting states see: http://www.uncitral.org/uncitral_texts/transport_goods/Hamburg_status.html. Accessed on 12 September 2013.

44 Sturley Michael, "The UNCITRAL Carriage of Goods Conventions: Changes to Existing Law," CMI Year Book, (2007-2008). Notes that at a signing ceremony there were 16 original States (Congo, Ghana, Nigeria, Spain, Denmark, Greece, Norway, Switzerland, France, Guinea, Poland, Togo, Gabon, Netherlands, Senegal, and United States). Such signatories represent over 25 percent of the world trade volume, which is quite significant when compared to the Hamburg 
This Convention enters into force on the first day of the month following the expiration of one year after the date of deposit of the twentieth instrument of ratification, acceptance, approval or accession. $^{46}$

In addition to that, the signatory states are compelled to denounce other Conventions once the Rotterdam Rules come into force. ${ }^{47}$

Rules that attracted 34 signatories representing only 5 percent of world trade volume. Furthermore, 8 additional signatory states (Madagascar, Armenia, Cameroon, Niger, Mali, Luxembourg, Democratic Republic of Congo, and Sweden) added their feathers to the Convention. Out of these 24 signatories, Spain is the only country that ratified the Convention. Furthermore, Article 94(1) of the Convention provides that: 'This Convention enters into force on the first day of the month following the expiration of one year after the date of deposit of the twentieth instrument of ratification, acceptance, approval or accession."

45 Diamond Anthony, "The Rotterdam Rules," Lloyd's Maritime and Commercial Law Quarterly 4, (2009): 445. Notes that "The final text of the Convention, annexed to it, states that the Convention was "done at New York" on 11 December 2008. Unlike the titles of mediaeval Sea-Laws, the titles by which recent maritime law Conventions are known sometimes have little, or only a nominal, connection with the place where the proposed law was promulgated. The original Hague Rules were so called because they represented an amended form of a body of voluntary rules formulated at a meeting in the Hague and subsequently adopted by a Convention signed at Brussels on 25 August 1924. The so-called Visby Protocol of 1968 has no connection with the port of Visby (or Wisby) save that, following a conference held at Stockholm in 1963, some representatives of the CMI followed an arcane ritual of travelling to Visby for the specific purpose of signing a draft text in that port, a text which was later much amended in the course of a diplomatic conference held in two stages at Brussels in 1967 and 1968. The Hamburg Rules are an exception; they were indeed agreed at a UN diplomatic conference held at that port in March 1978 following much preparatory work done elsewhere. As to the Rotterdam Rules, they were discussed, negotiated and agreed in a number of places, none of which was Rotterdam, but, following their promulgation in New York, there was a signing ceremony at Rotterdam in September 2009, at which 16 countries signed the Convention. The decision to call the new Convention "the Rotterdam Rules" is a tribute to the support of the Netherlands Government and to the contribution of Professor G J van der Ziel of Erasmus University to the work of the CMI and the UNCITRAL Working Group in developing the rules."

46 Article 94(1) of the Rotterdam Rules.

47 Article 89(2): "A State that ratifies, accepts, approves or accedes to this Convention and is a party to the United Nations Convention on the Carriage of Goods by Sea concluded at Hamburg on $31^{\text {st }}$ March 1978 shall at the same time denounce that Convention by notifying the Secretary-General of the United 
Christened as "Maritime Plus" due to its wide topographical scope of coverage pertaining to international contracts of carriage embodying international maritime law where the place of receipt, loading, delivery or discharge is situated in a contracting state. ${ }^{48}$ The rationale behind the Rotterdam Rules is to cater for the evolution of modern containerised shipping throughout, possibility of effecting shipments delivery by door to door through a uniform and single contract of carriage legal regime without prejudice to the prevailing unimodal transport regimes. ${ }^{49}$

\section{FREEDOM OF CONTRACT UNDER THE ROTTERDAM RULES}

One of the Convention's most significant inventions is that under certain conditions, it allows for freedom of contract. Article 80 states that "the carrier and the shipper... may provide for greater or lesser rights, obligations, and liabilities than those imposed by this Convention," provided that the conditions are individually negotiated or prominently specified in the volume contract.

As with any right, the freedom being enjoyed by parties to the volume contract is neither absolute nor unlimited. As it is obtainable under the Hague-Visby and Hamburg Rules, parties are not allowed to vary, amend or contract out. ${ }^{50}$ Under the Rotterdam Rules, these relate to definite responsibilities and potential obligations pertaining

Nations to that effect, with a declaration that the denunciation is to take effect as from the date when this Convention enters into force in respect of that State."

Position Paper, International Chamber of Shipping, Convention on Contracts for the International Carriage of Goods Wholly or Partly by Sea, Press ReleaseUnited Nations Information Service, 24 January, 2011. www.uncitral.org Accessed on 23 September, 2013.

49 Zekos Dr. G.I., "Documentation in the 2007 Draft Convention on the Carriage of Goods Wholly or Partly by Sea," Neptunus, Revenue Electronique, Centre de Droit Maritime et Oceanique de Nantes 14, (2008):1. observes that "the Rotterdam Rules aim is twofold: first to modernize the regime generally for the traditional "tackle to tackle" and "port to port" carriage of goods; and secondly, to introduce innovative solutions to meet the demands of carriage of goods on "door to door" terms by which the carrier undertakes responsibility for not only the maritime leg but also the intermediate and final land, inland waterway or air leg, from receipt of the goods from the shipper until final delivery to the receiver. 
to the position of shippers and carriers which are so vital and invariable. However, this right does not apply to the following: article 14(a) and (b) on the rights and obligations regarding seaworthiness; article 29 on the shipper's obligation to provide information, instructions, and documents; article 32 on the shipper's obligation to inform about and mark dangerous goods; and article 61 on loss of right to limitation. These are super-mandatory provisions that cannot be derogated from. It is also possible to bind third parties, i.e., the consignee, to the derogations in the volume contract, provided that the third party is informed of and expressly consents to the derogations. ${ }^{51}$

Several states were reluctant to allow parties to the contract of carriage to deviate from the mandatory liability regime. Some argued against the inclusion of volume contracts into the Rotterdam Rules. They posited that the extent of freedom enjoyed by parties is akin to the unbridled freedom that heralded the pre-1924 era. Similarly, it was argued further that small shippers, who have only one carrier to turn to, would be forced to enter into transport agreements under unfavourable conditions. However, this is unlikely. Rather, the freight forwarders, who consolidate goods and ship under space charters, are the ones who might suffer in this situation. They will face mandatory rules, because they will act as carriers to small shippers and consignees and have no or minimal ability to derogate from the Convention's liability. At the same time, depending on their bargaining power, they might be subject to derogations of the carrier's liability in their space charter agreements with larger ocean carriers. Thus, a risk exists that freight forwarders will be squeezed between the industry and the carriers. This might lead to a situation where freight forwarders refuse to take on carrier's liability, and instead, return to the role of sole intermediaries because of the lack of back-to-back arrangements. In the long term, this would be

51 Schelin Johan, "UNCITRAL Convention on Carriage of Goods by Sea: Harmonization or De-Harmonization," Texas International Law Journal 44, (2008): 321. Wherein he notes that the degree to which parties will avail themselves of the possibility to deviate from the liability regime in the Convention remains unknown. Due to the third-party binding restrictions, parties will likely use the possibility to derogate from the Convention in two situations: (1) where there are large shipments between different industries, i.e., in so called long term industry shipping; or (2) in relation between ocean carriers and freight forwarders shipping large amounts of consolidated goods, i.e., in situations where goods are shipped under space charters. 
detrimental to small shippers, especially when it comes to multimodal transports. ${ }^{52}$

Eventually, some states that originally were against the concept of freedom of contract under the guise of volume contract reluctantly acceded to the concept, as a sequel to the assurances that carriers will not abuse it. Although a compromise was reached, there is still a window of possibility that this issue will constitute a clog for the ratification of the Rotterdam Rules.

\section{DEVELOPMENT OF VOLUME CONTRACT UNDER THE ROTTERDAM RULES}

From a historical perspective, the concept of "volume contract" owes its origin from the United States of America within the purview of the seaborne trade regulation under the arrangement of the so-called "Ocean Liner Service Agreement" (OSLA) otherwise referred to as "service contract." $"$ It is defined as follows:

A written contract, other than a bill of lading or a receipt, between one or more shippers and an individual ocean common carrier or an agreement between or among ocean common carriers in which the shipper or shippers makes a commitment to provide a certain volume or portion of cargo over a fixed time period, and the ocean common carrier or the agreement commits to a certain rate or rate schedule and a defined service level, such as assured space, transit time, port rotation, or similar service features. The contract may

Ibid.

53 Mukherjee Prohanto and Abhinayan Basu Bal, "Legal and Economic Analysis of the Volume Contract Concept under the Rotterdam Rules: Selected Issues in Perspective," Journal of Maritime Law \& Commerce 40, (2009): 579. Noting that "prior to 1984, all ocean freight to or from the United States moved under published tariffs and most international shipping lines belonged to liner conferences. These conferences are cartels whose memberships comprise seagoing common carriers engaged in providing sea transport services under a common tariff, deriving their legitimacy largely from statutory enactments supporting their contractual arrangements. The genesis of the conference system dates back to 1875 . The First liner conferences covered trade in routes between Britain and India at the behest of leading British carrier companies. Carriers in the United States followed the British example around the turn of the century. Liner shipping progressed under the conference system and remained largely unchanged until the mid-twentieth century when containerization became predominant." 
also specify provisions in the event of non-performance on the part of any party. ${ }^{54}$

In essence, shipping lines and liner conferences ${ }^{55}$ were allowed to enter into agreements known as service contracts with shippers under which the shipper would agree to provide a designated volume of cargo over a specified period of time. ${ }^{56}$ By so doing, the parties enjoy a great deal of freedom and autonomy as well as flexibility in the allocation of rights, obligations and liabilities to the extent of derogating from the Rules. ${ }^{5}$

Due to the significance of "volume contracts" to the seaborne trade, estimated to be the basis of about $80 \%$ of the transatlantic and transpacific trade, ${ }^{58}$ the Rotterdam Rules created a special package to accommodate the complexities of such trade especially freedom of parties to the volume contract. ${ }^{59}$

Inclusion of Volume contracts in the Rotterdam Rules is one of the contentious developments during negotiating the Rules. This is owing to the fact that parties to a volume contract have almost an unfettered freedom to contract out of the Rules', "general liability

54 Section 3(19) of the Shipping Act of 1984 as amended by the Ocean Shipping Reform Act of 1988, Pub. L. 105-228, 112 Stat. 1902 (1998).

55 Herman Amos, Shipping Conferences, (United States: Kluwer Law International, 1983), 16. Observes that "Liner shipping" is an industry term of art which means regularly scheduled common carriage of cargo by sea, which is now by far the predominant means of ocean transport but which has only existed since about the time of the Civil War. Similarly, Article 1(3) of the Rotterdam Rules defines "liner transportation" as a transportation service that is offered to the public through publication or similar means and includes transportation by ships operating on a regular schedule between specified ports in accordance with publicly available timetables of sailing dates.

Section 46 of the US Shipping Act (1984) as amended defines conference as "an association of ocean common carriers permitted, pursuant to an approved or effective agreement to engage in concerted activity and utilize a common tariff; but the term does not include a joint service, consortium, pooling, sailing, or transshipment arrangement.

57 Levinson Marc, "Two Cheers for Discrimination: Deregulation and Efficiency in the Reform of US Freight Transportation," Enterprise and Society 10, no. 01 (2009): 178.

58 Faria Estrella, and Jose Angelo, "Uniform Law for International Transport at UNCITRAL: New Times, New Players, and New Rules," Texas International Law Journal 44, (2008): 277.

59 Silberman Linda and Franco Ferrari, Getting to the Law Applicable to the Merits in International Arbitration and the Consequences of Getting it Wrong, (Coppenhages: Ashgate, 2010): 10. 
regime. ${ }^{60}$ Parties can decide to increase the threshold of liability, and reduce or vary the responsibility of the carrier for consequential losses. ${ }^{61}$ In essence, parties' autonomy to freely contract is well entrenched and protected by the Rules so much so that "parties who had hitherto shied away from bespoke contracts may find a renewed enthusiasm for them." 62 This is a novel arrangement peculiar to the Rotterdam Rules and has not been catered for under the previous Hague-Visby or Hamburg Rules.

\section{THE FUTURE ROLE OF VOLUME CONTRACTS UNDER THE ROTTERDAM RULES}

One of the most cardinal objectives of the Rotterdam Rules is to provide a modern and comprehensive legal regime capable of providing uniform and harmonious rules against the anachronistic and fragmented existing legal regimes (Hague, Hague-Visby and Hamburg Rules). ${ }^{63}$ Obviously, one of the best ways of attaining this noble objective would have been the inclusion of realistic and possible provisions for providing adequate balance to the bargaining powers of parties to the contract of carriage as currently envisaged

60 Tetley William, "Reform of Carriage of Goods-The UNCITRAL Draft and Senate COGSA," Tulane Maritime Law Journal 28, (2003): 1.

61 Thomas Rhidian, "And then there were the Rotterdam Rules," Editorial of the Journal of International Maritime Law 14, (2000): 189.

62 Ibid.

63 Nikaki Theodora and Baris Soyer, "New International Regime for Carriage of Goods by Sea: Contemporary, Certain, Inclusive and Efficient, or Just Another One for the Shelves," Berkeley Journal of International Law 30, (2012): 303. Noting "Rotterdam Rules have taken into cognizance the advance technological sophistication within the shipping industry by providing provisions capable of dealing with such development. For instance, in the last five decades, ships have become faster and easier to load and unload, and cargo now often reaches the port of discharge before the bill of lading. As a result, the industry began to experience delays at the port of discharge because of the traditional rule that delivery is only possible against the bill of lading. To circumvent these needless delays, Rotterdam Rules provide a comprehensive rule on electronic transport records to facilitate and simplify electronic trade". See also Alba, Manuel. "Electronic commerce provisions in the UNCITRAL Convention on Contracts for the International Carriage of Goods wholly or partly by Sea," Texas International Law Journal 44, (2008): 387 observing that the terms "electronic transport record" is used alongside the words "transport document" throughout the Rotterdam Rules. 
under the Rotterdam Rules. By so doing, the gap created by the Hague Regimes of turning a blind eye to providing an appropriate threshold for a well-balanced freedom of contract would be remedied by the Rotterdam Rules by the inclusion of the volume contract.

However, this bold attempt by the Rotterdam Rules in promoting uniformity is severely jeopardized by the fact that chapters on jurisdiction and arbitration are not mandatory on the Contracting States but rather optional. The Contracting States enjoy discretion to either "opt-in" for both, or either, or even none of the chapters on jurisdiction and arbitration. ${ }^{64}$ Similarly, even the states that have signed such a declaration may opt-out of the choice of the two chapters on jurisdiction and arbitration at any time by withdrawing their previous declaration. ${ }^{65}$ It is beyond doubt that the "opt-in" and "opt-out" mechanism will severely undermine the hope of attaining harmony in regulating carriage of goods by sea. ${ }^{66}$

Another major shortcoming to the successful implementation of the Rotterdam Rules is the position of the European Union (EU) countries concerning jurisdiction. It is quite difficult for the member state to opt-in for the jurisdiction chapter due to the existence of Brussels 1 Regulation (EC Regulation No. 44) being one of the most successful regional Conventions in Europe. ${ }^{67}$ This will undoubtedly undermine the prospect of the Rotterdam Rules especially when some

64 Nikaki Theodora and Baris Soyer, "New International Regime for Carriage of Goods by Sea: Contemporary, Certain, Inclusive and Efficient, or Just Another One for the Shelves," Berkeley Journal of International Law 30, (2012): 303. "It is doubtful that all the Contracting States will opt-in to the jurisdiction and arbitration proceedings. During negotiations, some states expressed hostility toward adoption of these provisions. Thus, the final opt-in solution reflects a delicate compromise designed to improve the probability of adoption of the new convention. In essence, the opt-in approach was adopted as a compromise solution as it was felt that the mandatory application of the jurisdiction and arbitration provisions might have created barriers." Article 91(5) Rotterdam Rules. The State can opt-out by declaring an intention.

66 Tetley William, "Reform of Carriage of Goods-The UNCITRAL Draft and Senate COGSA," Tulane Maritime Law Journal 28, (2003): 1.

67 The Brussels 1 Regulation was further amended in December 2012. Regulation (EU) 1215/2012, of the European Parliament and of the Council of 12 December on Jurisdiction and the Recognition and Enforcement of Judgments in Civil and Commercial Matters (Recast), 2012 O.J. (L 351) 1 (EU); See also Schelin Johan, "UNCITRAL Convention on Carriage of Goods by Sea: Harmonization or DeHarmonization," Texas International Law Journal 44, (2008): 321. Observes that EU Member States owe an obligation to implement EC Directives and EC Regulation. 
of these European Member States are among the leading shipping industries in the world.

It is evident that jurisdiction and arbitration chapters mirror the concession achieved in order to enable the smooth sailing, tremendous popularity as well as accomplishing the anticipated uniformity within the disjointed regime. The two chapters are a facsimile of "evolutionary" as opposed to "evolutionary" transformation, by following the footsteps of Hamburg Rules. ${ }^{68}$ However, a critical examination of the concept of jurisdiction and arbitration chapters under Rotterdam Rules will disclose that they are yet to come up with the requisite solution for multimodal transport. $A$ fortiori, if the Contracting States are unanimous to regulate liability, it is needless to have definite rules limiting party choice thereby impeding the freedom of parties to the contract of carriage.

Likewise, the Rules are rather complex and restrictive than their counterparts under the English common law rules, European EC Regulation or New York Convention ${ }^{69}$ where no attempt whatsoever was made to demarcate a boundary between volume contract and other contracts, a discrepancy that is tough to rationalise. ${ }^{70}$

And like the Rotterdam Rules as a whole, the jurisdiction and arbitration chapters are largely pragmatic. They are drafted with a view to establishing a system that will meet the practical needs of the governed industry with little concern for theoretical elegance. ${ }^{71}$ The policies were driven by the demands of the industry rather than by the sensibilities of lawyers and academic experts. Although some nations will choose not to opt in to the jurisdiction and arbitration chapters, their inclusion in the Convention is nevertheless an important step toward the successful completion of the Rotterdam Rules, and thus

68 Tetley William, "Uniformity of International Private Maritime Law-the Pros, Cons, and Alternatives to International Conventions-how to adopt an International Convention," Tulane Maritime Law Journal 24, (1999): 775.

See United Nations Commission on International Trade Law, 1958 Convention on the Recognition and Enforcement of Foreign Arbitral Awards the 'New York' Convention at http://www.uncitral.org/uncitral/en/uncitral_texts/arbitration/NYConvention.htm 1 last visited, February, 2013.

70 Gaskell Nicholas, Regina Asariotis, and Yvonne Baatz, Bills of Lading: Law and Contracts, (London: Informa Law, 2000), 11-101. Ibid. 
restoring international uniformity to the rules governing the carriage of goods in maritime commerce. ${ }^{72}$

Summing up the whole gamut of the Rotterdam Rules, Professor Rhidian Thomas observed thus:

Few would deny the need for reform but whether the proposed Rotterdam Rules show the way forward must be doubtful. The lessons of history appear not to have been digested. The resistance of many Hague Rules states to the adoption of the Visby Protocol, the rejection by leading trading nations of the Hamburg Rules, and the unqualified rejection of the 1980 Convention on Multimodal Transport must communicate some kind of message. If nothing else it reveals a commercial world broadly content with the philosophy of the Hague regime and resistant to radical change. The feeling lingers that a small number of very necessary amendments to the Hague regime would have been more acceptable and more likely to succeed.

For the Rotterdam Rules to become expedient, it is crucial for the competing key players in the shipping industry to bury the hatchet and adopt a holistic step towards embracing the Convention.

\section{CONCLUSION}

The history of the law of carriage of goods by sea conventions is the account of the gradual phasing out of the laissez faire principle by introducing mandatory rules on liability. Towards the tail end of nineteenth century, carriers were exercising enormous and unfettered bargaining power over shippers under the guise of "freedom of contract" to stipulate all sorts of incongruous contractual terms as they deemed fit. However, an attempt was made to halt this practice by the United States in 1893 by introducing the Harter Act, which was followed by the first international mandatory legal regime regulating carriage of goods by sea in 1924, i.e. Hague Rules as amended by Hague-Visby Rules. The importance of shielding shippers and cargo owners found a new voice with the emergence of developing countries in collaboration with the United Nations

72 Thomas Rhidian, "And then there were the Rotterdam Rules," Editorial of the Journal of International Maritime Law 14, (2000): 189.

73

Ibid. at 202 
Conference on Trade and Development (UNCTAD) and led to the emergence of Hamburg Rules. The uncertainties heralding these legal regimes prompted some countries to be neither here nor there (with respect to Hague-Visby/Hamburg Rules) by promulgating local legislation adopting a hybrid regime. The Comite Maritime International (CMI) along with the United Nations Commission on International Trade Law (UNCITRAL) recently adopted a new convention (Rotterdam Rules but not yet in force), which is far reaching than the existing conventions to accommodate the emerging modern realities in the shipping industry.

The overall result of these legislative summersaults undermines significantly the need to reach the promised land of certainty, uniformity, and a "true-contractual freedom" in the contract of carriage. Unfortunately, the emergence of Hamburg Rules, which were later developed as an alternative to the Hague-Visby regime with a view to redressing the imbalance between the interests of shippers and carriers, contributed to the polarisation and fragmentation of the situation and failed to attract the support of major shipping powers. As a result, the Hamburg Rules frustrated the hopes of achieving a global uniformity and harmony in this field by creating yet another international carriage regime that applies to a truncated proportion of international shipping contracts.

At present, contract of carriage of goods is bedeviled with diverse conventions that have so far defeated the spirit and intendment of certainty and uniformity. An attempt to regulate freedom of contract and create a balance between the contracting parties has so far yielded a little result with parties taking the undue advantage of the loopholes created by the rules in resorting to forum shopping. Although, no Convention is perfect so also are the Rotterdam Rules. Despite its apparent imperfection and shortcomings, the Convention is allencompassing and well-balanced to cater for the modern challenges of international carriage of goods by sea. A fortiori, the existence of fragmented, divergent and anachronistic regimes attests to the viability of supporting the Rotterdam Rules. 